

\section{Testing The 'Black Swan Effect' on Croatian Stock Market Between 2000 and 2013}

\author{
Anita Radman Peša \\ Ana Brajković
}

\section{Introduction}

After the collapse of communist and socialist regimes in early 1990s, a number of Central and Eastern European (CEE) economies established capital markets as part of their transition process of adopting market economy mechanisms (Kim et al. 2005). Following the removal of restrictions on capital flows, the opening up to foreign investors, the creation of appropriate corporate governance structures and the establishment of ownership rights, both market capitalization and daily trading volumes increased rapidly in the CEECs during the transition period (Égert and Kočenda, 2007).

In recent years, Croatia has reduced the lag in the development of its financial system to the more advanced transition countries. The greatest progress has been made in increasing the size and activity of banks, where the Croatian banking system cannot compare equally with the banking systems of advanced transition countries. However, comparison with the activity of banks in developed countries shows that, in all transition countries there is scope for further strengthening bank activities towards the private sector. Initiating pension reform and the rapid growth of open investment funds soon will close the gap in the development of Croatian non-bank intermediaries. The largest lag behind advanced transition countries is therefore in capital market development. However, perspectives of development of the capital market today are different than before. Development of pension and investment funds created active institutional investors. In other words, obstacles to the development of capital market that are arising from the absence of quality demand are removed (Dalić, 2002). Although the capital marketing in our area is quite young and undeveloped, in recent years it has increased its popularity and many citizens have became owners of shares through public offerings, or before that, the privatization of enterprises. Still, there are many uncertainties which investors face every day.

Croatia has been struggling with recession and poor prospects of recovery for the sixth year in a row. Structural adjustment measures are still lacking, while positive developments in net exports and growth in manufacturing (spurred primarily by foreign demand) are slowly fading. The necessary preconditions for a recovery are still not in place, and on the contrary, most of the well-known structural problems (low competitiveness, weak labour market, administrative barriers, etc.) remain. Domestic demand is still hampered by the weaknesses in the labour market, continued corporate deleveraging and widespread consumer pessimism (Croatia Country Report, 2014).

The Zagreb Stock Exchange in Croatia was founded in 1991 as a profit-making corporation with HRK 2.7 million in registered capital, with the main stock indices CROBEX which were launched on 1 September 1997 with an initial value of 1000 points. While the capital market in Croatia remains small, fragmented and underdeveloped compared to the capital markets of developed countries, the Zagreb Stock Exchange has the highest market capitalization and volume of trade (25 companies) in the region. Drawing upon the methods used by authors who have dealt with the correlation of stock market indices, we researched and analyzed the correlation of stock market indices in Croatia (as a country preparing for EU accession) in order to investigate "The Black Swan" effect. Black Swan (Taleb, 2009) is an unpredictable event with serious consequences, and after its occurrence, people tend to think of explanations making this event predictable. Events with Black Swan label have appeared and keep appearing in variety of activities such as World Trade Center terrorist attack, economic crisis 2008 and rise of the internet. A major field of interest is Black Swan that occurs in financial management and risk management. What they have in common is the fact that nobody could even imagine their existence, based on all available information on past events, and because of the impossibility of their forecast or adjustment to these consequences, people classify them as impossible.

The topic of research is Croatian capital market in which authors wanted to examine the effect of Black Swan event on case of resignation of Prime Minister Ivo Sanader in 2009. The purpose of the following research is to prove that the resignationof Croatian Prime Minister Sanader, who had been previously successfully preparing the country for EU membership, is associated with corruption. This corruption has influenced the slow down of economic activity, together with the impact of the global crisis.

This research was done with the aid of OLS (Ordinary Least Square) regression. We examined the procyclicality of the Croatian stock market over a thirteen years transitional period - from January 2000 to December 2013 - on monthly bases. The local stock price indices (closing prices) - CROBEX (Croatia) - is in the focus of our research. 
The following chapters are structured as follows: Chapter 2 presents the theoretical background of the empirical analysis and an empirical literature on assessing financial integration in EU. Political and economical environment are following in Chapter 3. The macro-economic environment and stock exchange development in Croatia are described in Chapter 4. An explanation of the methodology and data underpinning the empirical analysis is given in Chapter 5 , as are the findings and discussion. The implications of the empirical analysis are revisited in the conclusion in Chapter 6.

\section{The theoretical background of empirical analysis and empirical literature concerning the stock exchange and black swan}

\subsection{Measuring the stock exchange}

Baltzer et al. (2008) considered three broad categories of financial integration in the measures proposed by Adam et al. (2002) and Baele et al. (2004). The market is considered fully integrated if all economic agents with similarly relevant characteristics acting in a market face a single set of rules, have equal access and are treated equally. This serves as an imaginary state of perfect integration, which is not often seen in practice but provides a useful benchmark for measuring the degree of financial integration.

Adam et al. (2002) adopted the law of one price to assess the degree of financial integration. According to the law of one price, the financial market is integrated if the 'law of one price' holds. This, however, cannot be measured when different stock exchange indices are involved as it would require a different methodology of calculation. According to the 'law of one price', assets with identical risks and return characteristics should have the same price regardless of where they are traded. ${ }^{1}$

Additionally, the law of one price does not necessarily hold true in the presence of market frictions. Nevertheless, while the law of one price represents a rather long-term phenomenon, an alternative argument for why we could expect the equalization of stock market returns in the long to medium run is based on the Walras law of markets, as applied to the financial system: if $n-1$ (financial) markets are in equilibrium (i.e. the exchange rate, money and bond markets), then the stock exchange market cannot be in disequilibrium.

Adam et al. (2002) also divided indicators for measuring financial integration into four categories: 1) indicators of credit and bond market integration; 2) indicators of stock market integration; 3) indicators of

\footnotetext{
${ }^{1}$ However, there are cases where the law of one price is not directly applicable. For more details see Baltzer et al. (2008).
}

integration based on the economic decisions of households and firms, and 4) indicators of institutional differences that may induce financial market segmentation. Indicators of European stock market integration generally suggest an increasing degree of stock market integration in the Euro area.

With regard to the indicators of stock market integration, Adam et al. (2002) proposed the correlation of stock market returns as an alternative indicator, especially because of its consistency. This is in contrast to a price-based indicator which relies on the asset pricing model and is difficult to estimate as it requires longer time series to provide reliable estimates. Baltzerat al. (2008) also suggests more sophisticated measures of co-movements (see also: Gerard et al. 2003).

Therefore, Baele et al. (2004) agree that, the alternative measures proposed by Adam et al. (2002) based on stocks and the flow of assets -- quantity-based measures $^{2}$ and news-based measures -- may complement price-based measures.

News-based measures, which were applied in this empirical research, analyze the impact that common factors have on the return process of an asset. The prediction is that the degree of systematic risk is identical across assets in different countries. They are designed to distinguish the information effects from other frictions and barriers. In a financially integrated area, one would expect news of a regional character to have little impact on prices, whereas global news should be relatively more significant.

Regional financial integration should increase the supply of finance in the less financially developed countries of the integrating area. Baale at al. (2004) maintain that when markets are fully integrated, bond yields should react only to news that is common to all observed markets. There is no clear evidence that full integration of financial markets is the result of monetary integration. The level of integration depends on the debt levels of the financial sector, and the economy abroad, as well as on the structure of the financial sector and its abilities to repay its loans abroad (current events inside the euro area are proof of this).

\footnotetext{
${ }^{2}$ Quantity-based measures that aim to quantify the effects of friction on the demand for, and supply of, securities by using variables such as money, bonds, shares and loans through the statistic of cross-border activities and listings.
} 
The Fratzscher (2002) and Cappiello's et al. (2006) findings indicated that, although new EU member states experienced rapid development in their financial markets, they exhibited differing degrees of integration and different speeds of convergence with the eurozone. While global trends significantly increased index movements, regional characteristics nevertheless remained the most significant determinants of integration. Authors conclude that European equity markets have become mutually more integrated and have gained in importance in world financial markets since 1996, with exchange rate variability having been reduced in the meantime. The convergence of interest rates is suggested to be the driving force behind these outcomes and there has been an increased correlation between stock returns within the Euro since the announcement of new eurozone members in May 1998.

The world capital markets, definitely, have become more and more integrated in the last 30 years, although some exceptions and some dispersion across the countries and sectors need to be acknowledged (see: Carrieri et al., 2007). European financial markets (Erdogan, 2008) have faced crucial structural and institutional adjustments with the aim of accelerating financial integration in the money, credit, bond, and equity markets. Integrated stock markets generate better opportunities for international investors by eliminating country-specific risks and allowing them to diversify their portfolios across countries. A larger pool of funds, other than limited local financing, is available for corporations. Integrated stock markets decrease the cost of capital. In an economic environment where better risksharing opportunities exist, households will be able to smooth their consumption more efficiently. Moreover, interdependent stock markets are subject to spillovers resulting from shocks.

Many authors dealing with financial integration have tested the procyclicality of stock exchange indices of whom we will single out those who have tested equity market integration in the EU.

Financial markets of new member states are significantly less integrated than those of the EU financial market and more susceptible to euro market shocks after EU accession. The process of financial integration of new EU member states is probably driven by factors different from those in the euro area. Nevertheless, there is strong evidence that their process of integration is well under way and has accelerated since accession to the EU. The transition from centrally planned to market economies has led to rapid financial developments boosted by a strong foreign, primarily EU banking, presence (Baltzer et al., 2008). ${ }^{3}$

Baele et al. (2004) investigated comovements between the stock markets in new EU member states from former communist states of Central and Eastern Europe in the period from 2000 to 2007. They found empirical evidence that the stock markets of entrant countries in the euro area were more exposed to adverse comovements, volatility, and persistence after their accession. This result suggests that the flip side of financial-market integration is stronger cross-country shock propagation.

Horská (2005) found that, the correlation among the Czech, US and European stock markets has increased over time, leaving less room for portfolio diversification. Syllignakis and Kouretas (2006) used Granger's (1995) methodology to identify, estimate and test a number of common trends among a group of examined stock markets. Author also applied the Markov Switching ARCH-L (SWARCH-L) model applied by Hamilton (1994) to study the structural breaks in volatility of the examined markets during the relevant period.

Savva and Aslanidis (2007) used the STCCGARCH methodology to investigate the degree of stock market correlation among five new EU members and the eurozone and demonstrated that the correlation between the Czech and Polish markets and the euro zone has been increasing over the past years, although the phenomenon cannot be said to be widely present in all the transition countries. They have also shown that new EU members have closer ties with the eurozone market than with the US market.

Onay (2007) used the Engle-Granger (1987) causality test to present evidence of a causal flow from European and US equity markets to the Croatian stock market, and from the Turkish to the Bulgarian stock market. The long-term stock market interdependence indicated no long-term relationship between the secondround countries and the EU and US stock markets.

Christiansen and Ranaldo (2008) used a multinomial logit model to investigate stock market integration in ten new EU member states. They demonstrated a higher degree of mutual relationship and dependence on the European stock market, especially after EU enlargement in 2004. The new EU markets have become more integrated with old EU markets and more related to the euro.

${ }^{3}$ The percentage of asset shares of foreign-owned banks (relative to total bank sector assets) increased from 30\% in 1997 to cca $75 \%$ in 2005 ( Baltzer et al. 2008). 
Vizek and Dadić (2006) used the Johansen cointegration test for measuring equity markets in CEE. The findings indicate multilateral integration between the equity markets of analyzed CEE economies. Latković (2002) and Levaj et al. (2005) used the main Croatian stock market index (Podravka company's stock data) and a few company indices to estimate a GARCH model and illustrate how this model can be used in volatility forecasting. Žiković (2006) applied a VaR (Value-at-Risk) methodology and historical simulation of the Croatian stock market indices in an effort to measure $\mathrm{VaR}$, calendar effects, and their impact on conditional volatility.

Hanousek et al. (2009) estimated the impact of macroeconomic news on composite stock returns in three emerging European Union financial markets (the Budapest BUX, Prague PX-50, and Warsaw WIG-20), using intraday data and macroeconomic announcements. They found that all three new EU stock markets are subject to significant spillovers directly through the composite index returns from the EU, the U.S. and neighboring markets; Budapest exhibits the strongest spillover effect, followed by Warsaw and Prague. The Czech and Hungarian markets are also subject to spillovers indirectly through the transmission of macroeconomic news. The impact of EU-wide announcements is evidenced more in the case of Hungary, while the Czech market is more impacted by U.S. news. The Polish market is marginally affected by EU news.

In other case, Egert and Kočenda (2007) examined intraday comovements among three developed (France, Germany, and the United Kingdom) and three emerging (the Czech Republic, Hungary and Poland) European stock markets. They applied a Dynamic Conditional Correlation GARCH model to five-minute tick intraday stock price data (2003-2006) and found a strong correlation between the German and French markets and also between these two markets and the UK stock market. However, very little systematic positive correlation during a trading day can be detected between the developed and emerging stock markets, or within the emerging group itself. Hungary exhibits higher correlation with the developing markets and the emerging markets, and its dynamics show a rising trend.

Intraday data were also in the focus of Černý and Koblas (2008) who studied stock market integration and the speed of information transmission on intraday data or even less frequent observations. They also studied the effect of macroeconomic releases (market returns, volatility and trading volumes) from different countries on different markets through high-frequency index data from markets in the U.S. and London. The authors suggest that, the speed of information transmission on stock markets is very high and that in most cases it is within one hour that a reaction to stock prices occurs. With integrated stock markets, information originating from one market should be important to other markets. They found out that, stock markets in Warsaw and Krakow depend on the movements of the Frankfurt Stock Exchange, but not vice versa. The three small Eastern European markets in Warsaw, Prague and Budapest react to information revealed in the market in Frankfurt usually within 40 minutes to an hour. The U.S. market seems to be an important source of information for the markets in London and Frankfurt which react to such information within approximately 30 to 40 minutes, with the strongest reaction in the first ten minutes. The markets in London, Frankfurt and Paris react to information within one hour, while the strongest reaction is detected after 20 minutes. They found that the strongest reaction is in the FTSE index.

Dvorák and Podpiera (2006) applied the betaconvergence method and observed an increase in stock prices in candidate countries once EU enlargement was announced. They investigated the hypothesis that the rise in stock prices was the result of the reprising of systematic risk due to the integration of accession countries into the world market. They found that firmlevel stock price changes were positively related to the difference between a firm's local and world market betas. The evidence suggests that at least part of the stock price increase can be explained by the difference between stocks' local and world betas. Stocks that had a high local beta but a low world beta experienced a higher price increase than other stocks.

Égert and Koubaa (2004) investigated the conditional variance patterns in the daily return series of stock market indices in the G-7 and six selected economies of Central and Eastern Europe. The stock markets in the transition economies exhibit much more asymmetry because negative shocks hitting these markets offset the positive news.

\subsection{The Black Swan Theory}

Before the discovery of Australia, people in the Old World were convinced that all swans were white (Taleb, 2009). Among other animal species in Australia, Willem de Vlamingh discovered the dark, feathered birds that are reminiscent of the swans (Taleb, 2007). Seeing the first black swan came as a surprise to ornitologists (as well as others who are interested in the colors of birds). Since then, the emergence of black swans, although previously completely unthinkable, became common (Taleb, 2004). 
Wall Street trader and philosopher, professor and author N.N.Taleb, is creator of the term "Black Swan" (Brunaker, 2013). Black Swan was first mentioned inTaleb's book "Fool by randomness" (2001), and is used as a metaphor for very rare events.

According to Taleb (2004), in his second book, Black Swan: The Impact of Highly Improbable, he defines in detail the Black Swan and explains the three criteria that describe it: a rarity, extreme impact, and retrospective explanation (Brunaker, 2013).

What is called the Black Swan is an event with three specific characteristics. First, it is atypical, since it is beyond the scope of regular expectations, and since for it there is no indication in the past. Second,the impact is extreme. And third, despite the atypical status, human nature tries to explain its occurrence and make it explanatory and predictable (Taleb, 2009).

Black Swan is atypical because it lies outside of regular expectations, and nothing in the past can not point its appearance (Estrada, 2009). Furthermore, Black Swan has an extreme impact because its appearance affects the whole society and has great consequences. The impact of this unpredictable phenomenon can be classified as positive or negative.

Positive Black Swan has favorable implications for development, such as the discovery of a new drug, the internet or the development of mobile phones. All of these examples were not conceivable before they were created, but they left positive impact upon their success.

In contrast, negative Black Swan comes with unsuitable and potentially catastrophic consequences, such as the economic crisis or the September 11 attack. Behind each characteristic of Black Swan, the importance of this type of event is in a large impact on daily activities. The impact of the Black Swan can radically change the way of life of the entire society. Characteristic of retrospection has its origins in the beliefs that human thought is comprehensive in its ability to explain the phenomenon of huge amounts, when in fact, explains a lot less than it is believed (Casto, 2012). Estrada (2009) points out that the retrospective explanation implies that, despite being an atypical event, people are trying to find it in some past events, to explain its formations and making it predictable event.

A few Black Swans can explain almost everything in this world, from the success of ideas and religions, through dynamic historical events to the elements of our own lives. (Taleb, 2009). The effect of Black Swan events increased over the years, and during the Industrial Revolution began to be accelerated. The world has become more complicated, while the usual events, the ones that we learn and discuss about, have became less important (Taleb, 2004).
Characteristics of the element of surprise (Black Swan) cause a condition that can not be directly learnt from the past, considering that it is already incorporated in the expectations of agents, thus leading to amodification of their behavior. To put it simply, the next time such an event occurs, it stops being asurprise and the damage will no longer be the same. Unfortunately, we can not perform methods in order to interfer the probability of developing the Black Swan event from inductive statistical methods (those based on observations from the past) and derivation of probability of future events (based on discoveries). However, statistics is what we instinctively resort to in social sciences. Scientific research on rare events, especially in the economy, are hampered because of a mechanism that is called in psychology hindsight bias, that assumes that after the actual occurrence of the event, it suddenly becomes convincing, even obvious (Taleb, 2003).

Many investors believe that their long-term returns are earned smoothly and steadily over time and that their capital came slowly, but as such is safe. This point of view is advocated by many academics who based on the hypothesis of normally distributed returns think that the Black Swans are extreme events that do not occur frequently and appear as an anomaly that is easy to ignore. The reality is, however, different .(Estrada, 2009)

The Black Swan is an event that can not be predicted in advance. In econometrics and statistics, Black Swan is considered atypical and represents the value or number that differs from the rest of the known and available.Through his book, Taleb believes all changes in human life are the result of randomnesa and uncertainty, and the human inability to predict these events even by experts. Also, Black Swan is not only the occurrence of an unexpected event, but also the absence of the expected (Brunaker, 2013).

According to Sniedovich (2012), Black Swan has a large impact on the lives of individuals and the evolution of the organization as it shapes each direction of history. However, because of its specific features (such as the one that it is a rare event), it comes out of the scope of the formal mathematical treatment. Taleb argues that reliance on such formal models, over the years, resulted in the wrong sense of security of decision makers in the financial sector and severe damages to the global financial system. Therefore, progress in this area will be achieved only if there is awareness that "We do not know how to deal with Black Swans" (Sniedovich,2012).

\section{Political and economical environment in Croatia in last decade}

Huckshorn (1984) defined political party as an autonomous group of citizens having the purpose of 
making nominations and contesting elections in hope of gaining control over governmental power through the capture of public offices and the organization of the government (Koruga et al., 2011).

Croatia today is a parliamentary democracy and is organized as a unitary republic. The social state, freedom, equality, equal rights and the rule of law are among the highest values of the constitutional order (The Miroslav Krleža Institue of Lexicography, 2013).

According to Bertelsmann Stiftung in Croatia Country Report (2014), Croatia's transition to democracy and a market economy in the 1990s was accompanied and constrained by the wars following the breakup of the former Yugoslavia. Political liberalization and Slobodan Milošević's nationalist mobilization campaign in Yugoslavia enabled the nationalist Croatian Democratic Union (HDZ) and its charismatic leader, Franjo Tuđman, to win the country's first democratic elections in May 1990. The new political leadership transformed Croatia into an ethnic nation-state by adopting a new constitution and by holding (and winning) a referendum on independence in May 1991. Croatia declared its independence in June 1991 (Bertelsmann Stiftung, 2014). Between 1990 and 2000, Croatia had a semi-presidential system, and since 2000 it has had a parliamentary system (European Parliament, 2010). The political system is based on the principle of the division of power into three branches: the legislative, the executive and the judiciary (The Miroslav Krleža Institue of Lexicography, 2013).

Two decades of political and economic transformation in Croatia can be divided into two phases. The first phase from 1990 until 2000 was marked by a highly complex and difficult triple transition: from an autocratic to a democratic political system, from a planned towards a market economy, and from a multinational Yugoslav federation into an independent national state. This third element of transition proved the most important, and it had a decisive effect on the dynamic and character of political and economic transformation (Bertelsmann Stiftung in Croatia Country Report, 2012).

The first political opposition parties also emerged at this time, among whom were the Croatian Democratic Union (HDZ) and the Croatian Social Liberal Alliance (HSLS), who fought the first free elections held in 1990. At those elections, HDZ won, becoming the dominant party in the period of the establishment of an independent Croatian state and the democratic political order in the 1990s (The Miroslav Krleža Institue of Lexicography, 2013).

These elections set the foundations for democratic legislative and executive government. At the same time, formal democratic institutions were out of sync with the predominantly authoritarian style of governance of Croatia's first President, Franjo Tuđman. Such tendencies were further exacerbated by the semipresidential system and the absolute majority that Tuđman's HDZ held in parliament (Bertelsmann Stiftung in Croatia Country Report, 2012).

As the party of Franjo Tuđman, who is widely seen as the father of independent Croatia, the right-ofcentre HDZ continues to be a major force in Croatian politics. In its more than 20 years of existence, the party underwent a number of transformations. In the 1990s, it was often characterized as a nationalistic and conservative-populist political entity. At the time of the 2011 Parliamentary elections, there were 116 parties officially registered in Croatia. However, a much smaller portion of these have established and maintained a major electoral presence on the political scene. The two parties that have consistently enjoyed the most electoral support in the past two decades are the HDZ and the SDP (European Policy Center, 2014).

The second phase of transformation started with the death of Franjo Tuđman in 1999 and the full change in government at the 2000 parliamentary and presidential elections (Bertelsmann Stiftung, 2012). According to Bertelsmann Stiftung (2014), after a decade of semi-authoritarian rule of by President Tuđman and the HDZ, an opposition coalition led by the Social Democratic Party (SDP) won the 2000 parliamentary elections. That was a boost for democratization in Croatia. These critical elections heralded a break with the previous hybrid regime and they forced HDZ to reform itself. During its period in office, the new government introduced institutional changes that aimed to strengthen the role of parliament and government in creating and implementing policies, to stem irregularities in the privatization process which were common in the previous decade and which destroyed part of the economy, and to increase the level of civil and political rights and freedoms in the country. Constitutional changes affected the abandonment of a semi-presidential system of government in favor of a parliamentary system (Bertelsmann Stiftung, 2014).

Despite undeniable economic and political accomplishments, the center-left coalition lost the subsequent election in 2003 (Bertelsmann Stiftung, 2012). Nevertheless, as the HDZ returned to power in 2003, the party did not signal its reluctance to cooperate and extradite indicted Croatian war criminals to ICTY. ${ }^{4}$

${ }^{4}$ International Criminal Tribunal for the former Yugoslavia or ICTY, is a body of the United Nations established to prosecute serious crimes committed during the wars in the former Yugoslavia, and to try their 
The best example of this was the arrest of fugitive General Ante Gotovina in 2005, which was conducted by the HDZ-led government (Bertelsmann Stiftung, 2014). HDZ returned to office under the leadership of Ivo Sanader.

The coalition government led by the Croatian Democratic Union (HDZ) was in power for eight years between 2003 and 2011 (Bertelsmann Stiftung, 2012). The strongest opposition party is the Social Democratic Party (SDP) with 56 seats in parliament, which came out at the 2007 general elections almost as strong as the HDZ. Only the votes from the significant Croatian Diaspora decided in HDZ's favour (European Parliament, 2010).

Research of European Parliament (2010) stated that, Croatia became a member of the North Atlantic Treaty Organization (NATO) together with Albania in April, 2009. Joining the European Union and NATO were important factors influencing Croatia's political transformation and democratization. Both organizations, especially the EU, offered clearly defined criteria for Croatian membership. This is particularly true for judicial reforms, the fight against corruption and emphasis on foreign policy, which should contribute to the stabilization of southeastern Europe (Bertelsmann Stiftung, 2014).

The evolving political crisis was symbolically announced by the surprise resignation of Ivo Sanader (HDZ) from the post of prime minister in July 2009 (Bertelsmann Stiftung, 2012). In July 2009, Jadranka Kosor became Prime Minister and the HDZ party leader following the surprise resignation of Ivo Sanader. She had to take over this position at a very critical moment, when the EU accession negotiations had been held up and an economic crisis had severe repercussions within the country. Besides the lost presidential elections, where the HDZ candidate Andrija Hebrang was already eliminated in the first round, she has succeeded in unblocking the accession negotiations. Furthermore, she is seen as the person who has been the most successful in boosting efforts to fight corruption.

On 3rd January 2010, the former Prime Minister Ivo Sanader announced, without having informed his party colleagues, his return to politics in order to ,tackle the evident leadership problems in the HDZ". This came as a shock to both the Prime Minister as well as to the coalition parties. As a consequence, the HDZ board expelled Sanader from the party on 4th January 2010 with the majority of HDZ members supporting this decision. Jadranka Kosor has further

perpetrators. The tribunal is an ad hoc court which is located in The Hague, Netherlands. strengthened her position and her control over the party. (European Parliament, 2010).

In both mandates, the HDZ has left behind an economically, socially and morally devastated country with a negative GDP rate, high unemployment, high internal insolvency, widespread corruption and a clientelist web, as well as non-transparent and authoritarian practices of political decision-making. However, in comparison with 2000, there have been some positive developments such as the much-improved international status of Croatia, reduced ethnic tensions in the country and indications that the rule of law is functional (Bertelsmann Stiftung, 2012).

In December 2011, amid parliamentary elections the Croatian Democratic Union (HDZ) lost power and the Social Democratic Party of Croatia (SDP) formed a new coalition government, led by Prime Minister Zoran Milanović. Finally, the effects of the economic crisis begun at the end of 2008, have yet to abate. In November 2012, a court in Zagreb convicted former Prime Minister Ivo Sanader on corruption charges and sentenced him to 10 years in jail. He was found guilty of accepting bribes for brokering a loan between the government and an Austrian bank in the mid-1990s, and for providing Mol, a Hungarian oil company, control over Croatian energy company Ina in 2008. While other corruption cases against other politicians and businessmen continue, Sanader's case is unprecedented in the history of modern Croatia as he is one of the highest-ranking state officials to be indicted. The Sanader case, among the many corruption cases being heard, not only shows that a serious effort to fight corruption is finally underway but also outlines the extent to which corruption has spread through Croatian society (Bertelsmann Stiftung, 2014).

\section{The Macroeconomic Environment and Stock Exchange Development in Croatia}

Croatia signed the Stabilization and Association Agreement (SAA) with the EU in 2001 and submitted a formal application for EU membership in 2003. The European Commission recommended opening accession negotiations and the European Council granted Croatia the status of an official candidate for EU membership in 2004. In 2005, accession negotiations were opened between the Republic of Croatia and EU. Although Croatia signed the SAA in 2001, EU Member States postponed the start of negotiations to March 2005 because they deemed Croatia's cooperation with the International Criminal Tribunal for the Former Yugoslavia insufficient. Croatia's EU accession negotiations were concluded in June 2011. The signing of the Accession Treaty and the referendum on EU accession took place in December 2011, with the full accession in July 2013. 
Recently, the Croatian government and other state agencies have started implementing demanding reforms, just as other countries of the SEE region, which have resulted in a record-breaking inflow of foreign investments and improved entrepreneurial climate until the global crisis started in 2008. The stock markets of SEE (including the Croatian stock market) have moved to align their standards with international ones by improving corporate disclosure practices, order execution, ownership rights, and by bringing down limitations to international capital flows (Syllignakis and Kouretas 2006). During EU accession negotiations, stock markets in Croatia received massive foreign investment inflows (32\% of equity investment), just as was the case with other EU candidate countries such as Bulgaria, Romania and Slovenia.

Less encouraging is the fact that those investments are directed more to the real estate and financial services, which means that they are less likely to generate exports revenue than if investments flowed into production. Stock exchanges in Croatia declined parallel to the world stock exchanges due to crisis.

The EU has adopted a financial package of EUR 3.7 billion for the first two years of Croatia's membership which were available through cohesion and structural funds. After the initial stages of the global crisis, Croatia has shown slower recovery than other SEE countries but the currency is strong and inflation is low thanks to the strict monetary policy of the Croatian National Bank. The main problem lies in the growing trade deficit and huge unemployment rate. In the course of 12 months, unemployment has risen by around $20 \%$.

Between 1994 and 2008, Croatian economy expressed relatively high rates of economic growth. One of the main drivers of growth of the national economy was the domestic demand, which in the period between 2001 and 2008 grew more than six percent per year (faster than growth of GDP). One of the signs of progress in the region was the inflow of direct foreign investments, especially before the crisis of 2008 started. Less encouraging is the fact that the investments were directed more to real estate and financial services, which means less of a probability of realizing export income than if investments were directed towards production. World crisis 2008 didn't bypass Croatia, but the country has got also its inner structural and economical problems. Between 2009 and 2010, there was a fall in real household consumption for nearly $10 \%$, as a result of the decline in the net real incomes which was reflected also as a reduction in the volume of imported goods. Over the years, the increased domestic demand, especially private consumption based on borrowing, was one of the causes of the continuous increase in total external debt (Benolić, 2012). The fall of the GDP rate and rise of unemployment in EU had a significant impact on
Croatian economy due to Croatian economic dependence on other EU members.

The focus of the new Croatian government was on domestic economic and social policies, with the promise to pull the country out of the crisis, but by the end of 2012 Croatia's GDP continued to fall. The government introduced a tax reform and began the restructuring of large state-owned companies. But projects that were supposed to boost the economy, such as investments, fell short. Moreover, the government failed to implement structural reforms to reduce public spending, and at the end of 2012, this failure resulted in a reduction of Croatia's debt rating. Although Croatian economic analysts often forecast lower economic growth numbers than those anticipated by the government, it was precise because of the country's expected entry into the European Union in 2013 that experts predicted had higher GDP growth in coming years (Bertelsmann Stiftung, 2014).

Generally, Croatia is a small open transition economy which has been largely connected to other foreign markets (Deskan - Škrbić et al., 2013). Currently, Germany is Croatia's very important trading partner and ranks third among foreign direct investors. Also, Austria is one of Croatia's most important partners in the foreign trade, direct investments, tourism and financial-banking sectors (CBS $\left.{ }^{5}, 2014\right)$. According to Sen et al. (2014), FDI generates positive productivity effects for host countries. The main mechanisms for these effects are the adoption of foreign technology and know-how, products by foreign firms, and the creation of linkages between foreign and domestic firms (Sen et al., 2014).

Macroeconomic stability in Croatia is under strong influence of global financial crisis. From 2009 to 2012, there have been a $11 \%$ loss for the real GDP, while personal consumption is reduced for $35 \%$, and investments is down for $11 \%$. Thus, poor results of the Croatian economy in the period from 2008 to 2013 generated increase in unemployment and government debt (Alpeza et al., 2014).

\section{Methodology and Data}

\subsection{Data specification}

Based on the studies investigating the correlation of stock market indices and macro economic variables in empirical literature, we constructed a data set of explanatory variables that are usually included in models: CAP: capital inflow expressed in percentage of GDP; EXR: exchange rate expressed as the price of one

\footnotetext{
${ }^{5}$ Croatian Bureau of Statistics
} 
unit of foreign currency in units of domestic currency; INT - interest rate, CPI: in bnp of domestic currency deflated by GDP deflator; UNE: unemployment expressed in percentage of the total labor force, NPL: non performing loanshare of all nominal loans that are at least 90 days overdue; We relied on the database of the European Commission (2010) ${ }^{6}$, and on the databases of the national statistical bureau.

We examined thirteen-year transitional period of research - a monthly time series from January 2000 to December 2013. For CROBEX, we also used the monthly average indices from January 2000 to December 2013.

\subsection{Methodology}

The individual Ordinary Least Square (OLS) method was used to uncover empirical evidence of a relationship between stock return indices and economic variables of Croatia. An OLS estimation was applied for the procyclicality of Croatian stock markets through the ten-year period of historical data (main economic indicators and CROBEX stock price (closing), on monthly bases from January 2000 to December 2013, in order to find the structural break when the analyzed cycles started to accelerate by using a Chow stability test (Andrews 1993 and Hansen 1997). The period from 2000 to 2013 was divided into two sub-periods. The first period between January 2000 and June 2009 was the period before the resignation of Croatian ex-vice premier Sanader. The second period from July 2009 to December 2013 was the period after the Sanader's resignation. We included the structural break in July 2009 which marks the resignation. Before applying linear regression methods, we eliminated the overly correlated explanatory variables (Appendix, Table A). We also collected variables such as exports and imports of goods and services, as well as trade balance and GDP, but we eliminated them in further analysis because they were highly correlated. Trade variables are known to be highly correlated and GDP is connected to a whole range of macroeconomic activities (Aizenman and Noy 2005).

All variables were seasonally adjusted through the seasonal adjustment method (Eviews 7) on the basis of 2000-2013 monthly data of Croatia's regression. We used the Augmented Dickey-Fuller (1979) test to examine a series for the presence of a unit root. According to test results, all variables are stationary in the form dlog (x) i.e. variables were integrated of order 1 (Table 1) (Dickey and Fuller 1979, Esaka 2003).

\footnotetext{
${ }^{6}$ Source:http://ec.europa.eu/economy_finance/db_indicat ors/cpaceq/index_en.htm (2010).
}

Table 1: The Stacionarity (Augmented Dickey-Fuller)

\begin{tabular}{|l|l|l|}
\hline Variable & Level & dlog(x) \\
\hline Capital inflow & -1.987277 & -12.81857 \\
& $(0.2923)$ & $(0.0000)$ \\
\hline Exchange rate & -0.103444 & -11.61809 \\
& $(0.9462)$ & $(0.0000)$ \\
\hline GDP & -1.435608 & -12.81589 \\
& $(0.5637)$ & $(0.0000)$ \\
\hline Government debt & 0.041906 & -1.039897 \\
& $(09601)$ & $(0.0000)$ \\
\hline Industrial production & -1.766906 & -12.81373 \\
index & $(0.3959)$ & $(0.0000)$ \\
\hline Interest rate & -2.793340 & -12.82575 \\
& $(0.0614)$ & $(0.0000)$ \\
\hline CPI & -2.448295 & -12.81967 \\
& $(0.1303)$ & $(0.0000)$ \\
\hline Trade balance & -3.448841 & -8.647871 \\
& $(0.0107)$ & $(0.0000)$ \\
\hline Unemployment & -1.361674 & -12.82600 \\
& $(0.5999)$ & $(0.0000)$ \\
\hline
\end{tabular}

To determine the lag length, we used the Schwarz Information Criterion - because the Schwarz criterion and its parsimonious model perform better over a longer period of research (Ashgar and Abid 2007) - as well as the Akaike and Hannan-Quinn Information Criterion (Akaike 1987). A maximum of twelve lags was considered for each variable when determining the lag length.

For testing serial correlation, we used the $Q$ statistic and the Breusch-Godfrey LM test (Appendix: Table B). Q-statistics were estimated to check autocorrelation in the residuals (Iwaisako 2004) by a test statistic for the null hypothesis that there is no autocorrelation of residuals with high probabilities and low Q-statistics. The results indicated that residuals are not serially correlated and, therefore, suitable for analysis.

\subsection{Results and discussion}

Croatia, as an EU new country, proved to be a suitable case study for the empirical research of procyclicality with reference to 'black swan' examination on a monthly basis from January 2000 to December 2013. The structural break was presumed to have occurred in July 2009, when the resignation of Croatian ex-prime minister Ivo Sanader was announced. In light of that unexpected event, the transition period in Croatia was divided into a first sub-period (from January 2000 to June 2009), while the second one was stretched from July 2009 to December 2013. Second sub-period involved the resignation of ex-Prime minister, as well the global financial crisis which spread beyond the national borders and didn't pass-by Croatia. The results of the stability test confirmed the hypothesis of the structural break due the resignation of Croatian prime minister and due the global financial crisis (probability 0.32) (see: Cappiello 
et al. 2006, Dvorák and Podpiera 2006). Rock and Bonnett (2004) verified the negative relationship between corruption and economic growth, and between corruption and investment. They came to the conclusion that, corruption is much more destructive to investment and economic growth in small against great developing countries.

The rise in stock prices in Croatia, as in other EU candidate countries were also followed by a significant capital inflow, stronger currency and low inflation. Arguably the most important factors driving the acceleration of financial integration are related to the policy measures undertaken by "new" member states in order to meet European financial standards, including the liberalization of capital accounts, as well as legal and institutional reforms (see: Poghosian 2008).

The reforms in Croatia started in 2005 with the opening of official negotiations (see: Mohammad and Abdelhak 2009, Glazar and Striekolwski 2010). Reforms implementation - including cuts in government spending - was a requirement for EU accession and a strong incentive for SEE countries on their way to EU membership. Just as other EU candidate countries in the process of EU accession, Croatia had to implement reforms aimed at spending cuts (for instance in the pension and welfare systems), while maintaining budgetary discipline and restructuring the public sector due to high deficits in the balance of payments and overspending (see Vizek and Dadić 2006, Dolenc and Laporšek 2010).

The positive environment that accompanied EU accession started reversing at the end of 2008, with the global recession and inner political instabilities (significant cases of corruption followed by many court trials) as well as lower consumer spending and lower industrial output (see Andrei et al., 2009). In 2008, Croatian ex-premier Sanader claimed that there is no crisis in Croatia. But after his resignation, Croatia faced serious economical and political problems produced by internal factors (corruption, decline of GDP, industrial production and employment) as well as external factors (global crisis). In 2011, Croatia government and other state bodies have started implementing demanding reforms, which have resulted in the slow rise of GDP in 2015 for the first time after 6 years and a better entrepreneurial climate.
Table 2: OLS - Croatia

\begin{tabular}{|c|c|c|c|}
\hline \multicolumn{4}{|c|}{ Dependent variable: $d \log (\mathrm{x})(01 \mathrm{~m} 2000$ to $12 \mathrm{~m} 2013)$} \\
\hline Variable & $\begin{array}{l}\text { (from January } \\
2000 \text { to } \\
\text { December } \\
2013 \text { ) }\end{array}$ & $\begin{array}{l}\text { (from January } \\
2000 \text { to June } \\
2009 \text { ) }\end{array}$ & $\begin{array}{l}\text { (from July } \\
2009 \text { to June } \\
2013 \text { ) }\end{array}$ \\
\hline $\begin{array}{l}\text { dlog } \\
\text { (CAP) } \\
(-8)\end{array}$ & $\begin{array}{l}0.041599 \\
(0.0269)^{* *}\end{array}$ & $\begin{array}{l}0.047800 \\
(0.0295)^{* *}\end{array}$ & $\begin{array}{l}0.044783 \\
(0.0250)^{* *}\end{array}$ \\
\hline $\begin{array}{l}\text { dlog } \\
(\text { EXR) } \\
(-12)\end{array}$ & $\begin{array}{l}-0.514578 \\
(0.0174)^{* *}\end{array}$ & $\begin{array}{l}-0.684046 \\
(0.0086)^{* * *}\end{array}$ & $\begin{array}{l}-0.718885 \\
(0.0140)^{* *}\end{array}$ \\
\hline $\begin{array}{l}\text { dlog (INT) } \\
(-11)\end{array}$ & $\begin{array}{l}-0.050348 \\
(0.0588)^{* *} \\
\end{array}$ & $\begin{array}{l}-0.092007 \\
(0.0108)^{* *}\end{array}$ & $\begin{array}{l}-0.083066 \\
(0.0019)^{* * *}\end{array}$ \\
\hline $\begin{array}{l}\text { dlog (CPI) } \\
(-4)\end{array}$ & $\begin{array}{l}0.064830 \\
(0.0069)^{* * *}\end{array}$ & $\begin{array}{l}0.084424 \\
(0.0146)^{* *}\end{array}$ & $\begin{array}{l}0.084784 \\
(0.0142)^{* *}\end{array}$ \\
\hline $\begin{array}{l}\text { dlog } \\
(\mathrm{UNE}) \\
(-12) \\
\end{array}$ & $\begin{array}{l}-0.243750 \\
(0.0044)^{* *}\end{array}$ & $\begin{array}{l}-0.275572 \\
(0.0107)^{* *}\end{array}$ & $\begin{array}{l}-0.222322 \\
(0.0343)^{* *}\end{array}$ \\
\hline \multirow{2}{*}{$\begin{array}{l}\text { dlog } \\
(\mathrm{NPL}) \\
(-3) \\
\end{array}$} & $\begin{array}{l}-0.182037 \\
\quad(0.0068)^{* * *}\end{array}$ & $\begin{array}{l}-0.203318 \\
(0.0125)^{* *}\end{array}$ & $\begin{array}{l}-0.258597 \\
(0.0125)^{* *}\end{array}$ \\
\hline & $\begin{array}{l}\text { Weighted } \\
\text { statistic }\end{array}$ & $\begin{array}{l}\text { Weighted } \\
\text { statistic }\end{array}$ & $\begin{array}{l}\text { Weighted } \\
\text { statistic }\end{array}$ \\
\hline R-squared & 0.311777 & 0.377188 & 0.464384 \\
\hline $\begin{array}{l}\text { Adjusted } \\
\text { R-squared }\end{array}$ & 0.280961 & 0.337007 & 0.386001 \\
\hline $\begin{array}{l}\text { S.E. of } \\
\text { regression }\end{array}$ & 0.050692 & 0.052389 & 0.035909 \\
\hline $\begin{array}{l}\text { Durbin- } \\
\text { Watson } \\
\text { stat. }\end{array}$ & 2.005705 & 2.000497 & 1.760090 \\
\hline $\begin{array}{l}\text { S.D. } \\
\text { dependent. } \\
\text { Var } \\
\end{array}$ & 0.059782 & 0.064341 & 0.045827 \\
\hline $\begin{array}{l}\text { Stability } \\
\text { test } \\
\text { (Chow } \\
\text { Breakpoint } \\
\text { Test) }^{\mathrm{i}}\end{array}$ & 0.3193 & - & - \\
\hline \multicolumn{4}{|c|}{$\begin{array}{l}\text { Variables: } \\
\text { CAP: capital inflow expressed in percentage of GDP; EXR: } \\
\text { exchange rate expressed as the price of one unit of foreign currency } \\
\text { in units of domestic currency; INT - interest rate p.a.; CPI: consumer } \\
\text { price index (in bnp of domestic currency deflated by GDP deflator); } \\
\text { UNE: unemployment expressed in percentage of the total labor force, } \\
\text { NPL: non performing loan (loan share of all nominal loans that are at } \\
\text { least } 90 \text { days overdue) }\end{array}$} \\
\hline \multicolumn{4}{|c|}{$\begin{array}{l}\text { Notes: } \\
\text { The time lag of the variables is given in subscript; (probabilities)*** } \\
\text { are in parentheses below. } \\
\text { Significance levels are denoted as: *** significant at } 1 \% \text {; ** } \\
\text { significant at } 5 \% \text {; significant at } 10 \% \text {. } \\
\text { i Probability of the Chi-Square distribution }(0.3193)\end{array}$} \\
\hline
\end{tabular}

As expected, we found a correlation among the main economic indicators and stock exchange indices of Croatia. We can confirm the positive influence of capital inflow and inflation on stock exchange indices 
(CROBEX) (see: Table 2). We also confirmed that exchange rate (depreciation), interest rate, unemployment and non-performing loans have a negative impact on stock exchange indices.

The rising stock prices in Croatia presented in our study provide evidence of economic growth in the region and financial integration process in general, and the EU integration process in particular. The increase in stock prices usually goes hand in hand with large foreign direct investment as well as the implementation of reforms related to EU integration. European financial markets (see: Erdogan 2008) have faced crucial structural and institutional adjustments with the aim of accelerating financial integration in the money, credit, bond, and equity markets. The process of integration should increase cross-border investments among countries which have joined the EU and are in the process of joining the European and Economic Monetary Union (more in: De Santis and Gerard 2006, Dvorák and Podpiera 2006, Christiansen and Ranaldo 2008).

The positive influence of capital inflow - which is obvious in the findings concerning Croatia's regression - reinforces the theory that foreign direct investments in developing economies have grown rapidly, following financial and political transformations (see: Berben and Jansen 2005, Horobet and Ilie 2007). The dramatic increase in stock prices in EU accession countries clearly followed the announcement of EU enlargement (for Bulgaria, Romania and Slovenia, and subsequently Croatia and Montenegro). Croatia's FDI inflows increased by up to EUR 1 billion, especially in 2005 (after the announcement of its EU candidate status). The most part of FDI inflow in Croatia was through the acquisition of existing companies (mostly through privatization of services sector, telecommunications and financial services).

The findings also confirmed the exchange rate as an important explanatory variable that has a significant impact on CROBEX. The depreciation of exchange rates has adverse effects on exporters and importers alike. Exporters have an advantage over those in other countries as their sales increase and their stock prices go up (see: Berben and Jansen 2005, Yau and Nieh, 2006 andHorobet and Ilie 2007, Adjasi et al. 2008, Knif et al. 2008). While Croatia imports goods and services rather than export them, the depreciation of exchange rates has a negative impact on the stock exchange rate. Like many other countries in the early phases of transition, Croatia relied mainly on exchange rate anchors to lower inflation. However, in the early 1990s most Southeastern and Central European countries pegged their currencies to the dollar or currency baskets, which contained both the dollar and European currencies, exchange rate strategies have been gradually redirected towards the euro (see: Schnabl 2004). Increased financial integration implies that the benefits from adopting the euro will increase over time. The Croatian kuna has gradually appreciated since the beginning of 2005 and exchange rate movements in Croatia are characterized by the usual seasonal pattern reflecting tourism. Evidence of a strong relationship between stock prices and exchange rates in the case of Croatia can also be explained by the fact that the Croatian economy partly depends on services such as tourism. Every year the exchange rate of the kuna vis-àvis the euro appreciates before the summer and depreciates by some $2.7 \%$ between August and October. Due to strong foreign exchange inflows in the high tourist season, the Croatian real exchange rate is under constant pressure to appreciate (Holzner 2005). Copeland (1991) showed that, appreciation of the real exchange rate is a significant mechanism allowing tourism to benefit the economy (Dajčman et al. 2013).

A negative result of interest rate and nonperforming rate is in line with the theory that stock market returns are usually negatively correlated to interest rates. A rather high interest rate is typical for transition countries due to insufficient national accumulation and available credit supply. The transition from planned to market economies in the SEE region has led to rapid financial developments. A strong presence of foreign banks (in the case of Croatia, Italian and Austrian banks feature the most) in those countries in the last decade did not seriously help in reducing interest rates, but it widened the supply of different financial products and services to the government, companies and households. Together with improved access to foreign loans provided by new private banks, this has helped to fuel a boom in lending in Croatia (see: Poghossian 2008 and Festić et al. 2009).

Until 2008, Croatia had the highest growth rate of loans that have been given to the private sector what is also one of the characteristics of transition countries. Many of these loans have been given to private individuals for the households which, after the crisis, become non performing loans because many people lost their jobs and payment ability. In Poland, Hungary as well as in Croatia, a large number of house buyers took out loans in foreign currencies, especially Swiss francs, before the crisis. In the past, those customers were lured by lower interest rates, yet they were not fully aware of the currency risk related to those loans (e.g. Reiffeisen bank and Erste bank). In particular, exchange rate depreciations might lead to an increase of nonperforming loans in countries with a high degree of lending in foreign currencies to unhedged borrowers (approximated by international claims which are mainly denominated in foreign currencies). A drop in stock prices also negatively affects bank asset quality, in particular in countries with large stock markets relative to the economy (Beck, 2013). 
Inflation and the stock exchange in Croatia are positively correlated in our research, confirming the Fisher hypothesis ${ }^{7}$ about positive correlation between inflation and stock exchange volatility (see more in:Muradoglu et al. 2001, Maysami et al. 2004, Knif et al. 2008, Adam and Tweneboah 2009). Croatia faced the highest inflation rate in 2009 but the national currency, the kuna, is stable. In an environment of ample liquidity and depressed economic activity, the Croatian National bank did not change its accommodative monetary policy stance in 2010.

In 2011, the alarming unemployment rate in Croatia stood at nearly $20 \%$ and this remains one of the main problems of the Croatian economy, together with a growing trade deficit, uneven regional development, a strained state budget and an over-reliance on tourism revenue. In 2011, Croatia government and other state bodies have started implementing demanding reforms, which have resulted in the slow rise of GDP in 2015 for the first time after 6 years and a better entrepreneurial climate.

\section{Conclusion}

Since its formal application for EU membership in 2001, Croatia has faced different political and economic problems such as the delayed start of accession negotiations over its deficient cooperation with the International Criminal Tribunal, significant cases of corruption, effects of global recession, lack of institutional reforms, growing budget deficit and high unemployment. Despite these problems, Croatia has over the past decade also seen some positive trends such as strong foreign direct investment followed by the establishment of a capital market, as part of its opening up to market economy. Capital inflow in Croatia (expecially high following the start of EU accession negotiations in 2005) boosted stock exchanges and occasioned a rise in GDP, industrial production and trade relations, especially with EU. The results of measuring the procyclicality of the Croatian stock market from January 2000 to December 2013 also implies that the resignation of Premier Sanader was a trigger for decline in stock prices and economic activities, following with belated recession in region. Facing the new economic conditions, country faced serious problems produced by internal factors (corruption, decline of GDP, industrial

\footnotetext{
${ }^{7}$ The Fisher hypothesis (1930) is that the market rate of interest comprises the expected real rate of interest and expected inflation. This hypothesis, when applied to stock markets, postulates a positive one-to-one relation between stock returns and inflation.
}

production and unemployment etc) as well as external factors (global crisis).

The findings of empirical analysis also proved that stock indices in Croatia are negatively correlated to exchange rates, interest rates, non-performing loans and unemployment rates. Real exchange rates are symptomatically procyclical in Croatia, as was the case with other countries in transition, because Croatia relied mainly on exchange rate anchors to keep inflation in check. A negative correlation was also confirmed for the interest rates due to a strong presence of foreign banks in Croatia and a different range of financial products they offer. High interest rates in Croatia, especially after the 2008 global recession, caused a decline in consumption and private and public sector lending.

In 2011, Croatia government and other state bodies have started implementing demanding reforms, which have resulted in the slow rise of GDP in 2015 for the first time after 6 years and a better entrepreneurial climate.

\section{REFERENCES}

Adam, K., Japelli, T., Menichini, A., Padula M., and Pagano, M. 2002. Analyse, Compare, and Apply Alternative Indicators and Monitoring Methodologies to Measure the Evolution of Capital Market Integration in the European Union. European Commission. 1-95.

Adam, A. M., and Tweneboah, G. 2009. Foreign Direct Investment and Stock Market Development: Ghana's Evidence. International Research Journal of Finance and Economics. 26: 178-185.

Adjasi, Ch., Harvey, S.K., and Agyapong, D. 2008. Effect of Exchange Rate Volatility on the Ghana Stock Exchange. African Journal of Accounting, Economics, Finance and Banking Research, 3(3).

Aizenman, J., and Noy, I. 2005. FDI and Trade - Two Way Linkages. NBER Working Paper. 11403.

Akaike, H. 1987. Factor Analysis and AIC. Psychometrika, 52(3): 317-332.

Andrei, T., Matei, A., Stancu, S., and Oancea, B. 2009. Some Notes About 
Decentralization Process Implication on Public Administration Corruption in Romania. Prague Economic Papers, 1: 26-37.

Andrews, D.W.K. 1993. Test for Parametar Instability and Structural Change with Unknown Change point. Econometrica, $61: 821-856$.

Ashgar, Z., and Abid, I. 2007. Performance of Lang Lenth Selection Criteria in Three Different Situtations. Interstat.

Babetskii, I., Komârek, L., and Komârkovâ, Z. 2007. Financial Integration of Stock Markets among New EU Member States and the Euro Area. Finance aúver - Czech Journal of Economics and Finance, 57, 341-362.

Baele, L., Ferrando, A., Hördahl, P., Krylova, E., and Monnet, C. 2004. Measuring Financial Integration in the Euro Area. Occasional paper Series, European Central Bank, 14: 1-93.

Baltzer, M., Cappiello, L., De Santis, R., and Manganelli, S. 2008. Measuring financial integration in the New EU Member States.Occasional Paper Series, European Central Bank, Vol.81.

Beck,R., Jakubik, P., and Piloiu, A. 2013. Non-performing loans what matters in addition to the economic cycle? Vol.1515.

Berben, R.P., and Jansen, W.J. 2005. Comovement in international equity markets: A sectoral view. Journal of International Money and Finance, 24: 832-857.

Bertelsmann Stiftung, BTI 2012 - Croatia Country Report.

Breusch, T. S., and Pagan, A. R. 1979. A Simple Test for Heteroskedasticity and Random Coefficient Variation. Econometrica. 48: 1287-1294.

Brunaker, F., and Nordqvist, A. 2013. A Performance Evaluation of Black Swan Investments. University of Gothenburg, Department of Economics, Bachleor Thesis.

Cappiello, L. Kadareja, G.A., and Manganelli, S. 2006. Financial Integration of New
EU Member States. ECB working paper Series. No.683.

Carrieri, F., Errunza, V., and Hogan, K. 2007. Characterizing World Market Integration through Time. Journal of Financial and Quantitative Analysis. 42(4): 915-940.

Castro, C. C. 2012. Black Swan Theory: We know absolutely nothing \& the finding of atypical events optimization-method.

Copeland, B. 1991. Tourism, Welfare and Deindustrialization in a Small Open Economy. Economica, 58: 515-529.

Černý, A., and Koblas, M. 2008. Stock Market Integration and the Speed of Information Transmission. Czech Journal of Economics and Finance, 58: 2-20.

Dajčman, S., Festić, M., and Kavkler, A. 2013. Long range dependence in the returns of three Central and Eastern European stock markets - a time-varying analysis. Transformations in Business \& Economics (TIBE) in print, Vol 12, 1 (28): 206-220.

Dalić, M. 2002. Usporedna analiza hrvatskog financijskog sustava i financijskih sustava naprednih tranzicijskih zemalja. Privredna kretanja i ekonomska politika. 92: 27-51.

De Santis, R. A., and Gérard, B. 2006. Financial integration, international portfolio choice and the European Monetary Union. European Central Bank, Working Paper Series No.626.

Dickey, D.A., and Fuller, W.A. 1979. Distribution of the Estimators for Autoregressive Time Series with a Unit Root. Journal of the American Statistical Association. 74: 427-431.

Dolenc, P., and Laporšek, S. 2010. Tax Wedge on Labour and its Effects on Employment Growth in the European Union. Prague Economic Papers, 4: $344-358$.

Dvorák, T., and Podpiera, R. 2006. European Union enlargement and equity markets in accession countries. Emerging Markets Review, 7(2): 129-146. 
Égert, B.,and Kočenda, E. 2007. Interdependence between Eastern and Western European Stock Markets: Evidence from intraday data. Economic Systems, 31(2):184-203.

Égert, B., and Koubaa, Y. 2004. Modelling Stock Returns in the G-7 and in Selected CEE Economies: A Nonlinear GARCH Approach. William Davidson Institute Working Paper No.663.

Engle, R.F., and Granger C.W. 1987. Cointegration and Error Correction: Representation, Estimation and Testing. Econometrica. 55:51-276.

Erdogan, B. 2008. Financial Integration in the European Stock Markets', Working paper D. 1.1.a., Finess, European Commision.

Esaka, T. 2003. Panel Unit Root Tests of Purchasing Power Parity Between Japanese Cities, 1960 - 1998: disaggregated price data. Japan and the World Economy. 15 (2): 233-244.

Estrada, J. 2009. Black Swans in emerging Markets. Journal of Investing, 18(2): 50-56.

European Commission, 2010. EU Candidate and Pre-Accession Countries Economic Quarterly.

European Parliament, Directorate General for Internal Policies. 2010. The Economic and Political Situation in Croatia.

European Policy Center, 2014. EU Integration and party politics in the Balkans. PC Issue No.77.

Festić, M., Repina, S., and Kavkler, A. 2009. The Overheating of Five EU New Member States and Cyclicality of Systemic Risk in the Banking Sector. Journal of business economics and managemen. 10 (3): 219-232.

Fisher, I. 1930. The theory of interest. New York, Macmillan.

Fratzscher, M. 2002. Financial market integration in Europe: On the effects of EMU on stock markets. International
Journal of Finance and Economics. 7:165-193.

Gerard B., Hillion, P., and Roon, F. 2003. International Portfolio Diverzification: Industry, country and currency. Effects Revisited, Working paper.

Glazar, A., and Striekolwski, W. 2010. Turkey and the European Union: Possible Incidence of the Accession on Migration Flows. Prague Economic Papers. 3: 218 - 234.

Godfrey, L.G. 1978. Testing for Multiplicative Heteroscedasticity. Journal of Econometrics. 8: 227- 236.

Hanousek, J., Kočenda, E., and Kutan, A.M. 2009. The Reaction of Asset Prices to Macroeconomic Announcements in New EU Markets: Evidence from Intraday Data. Journal of Financial Stability, 5(2): 199-219.

Hansen, B. E. 1997. Approximate Asymptotic P-Values for Structural-Change Tests. Journal of Business and Economic Statistics. 15:60-67.

Holzner, M. 2005. Fear of Croatian Disease. Is there a danger of a Dutch Disease Effect with respect to a boom in the tourism sector in Croatia in the long run - 'The Croatian Disease'? WU Vienna University of Economics and Business, Doctoral thesis.

Horobet, A., and Ilie, L. 2007. On the Dynamic Link Between Stock Prices and Exchange Rates: Evidence from Romania. Munich Personal RePEc Archive, MPRA Paper No.6429.

Horská, H. 2005. Český Akciový Trh - Jeho Efektivnost a Makroekonomické Souvislosti. Finance a úvür. The Czech Journal of Economics and Finance. 55(56): 283-301.

Iwaisako, T. 2004. Stock Index Autocorrelation and CrossAutocorrelation of Size Sorted Portfolios in the Japanese market. Journal of Financial Economics. 3:283-301.

Johansen, S. 1988. Statistical Analysis of Cointegration Vectors. Journal of 
Economic Dynamics and Control. 12: 231-254.

Kim, S.J., Lucey, B.M., and Wu, E. 2005. Dynamics of Bond Market Integration between Existing And Accession EU Countries. The Institute for International Integration Studies Discussion Paper Series.

Knif, J., Kolari, J., and Pynnönen, S. 2008. Stock Market Reaction to Good and Bad Inflation News. Journal of Financial Research. 31(2):141-166.

Koruga, P., et al. 2011. Comparison of Communication of Political Parties over the Internet in Slovenia and Croatia. International Conference on Information Society.

Latković, M. 2002. Risk management: Identification, measurement and control. Finansijska Teorija i Praksa. 26(2): 463-477.

Levaj, L., Kamenarić, T., Mišković, J., and Mokrovčak, I. 2005. Metode obrade signala u ekonomiji. Sveučilište u Zagrebu, Fakultet Elektrotehnike i Računarstva.

Maysami, R. C., Howe, L. C., and Hamzah, M. A. 2004. Relationship between Macroeconomic Variables and Stock Market Indices: Cointegration Evidence from Stock Exchange of Singapore's All-S Sector Indices. Journal Pengurusan. 24: 47-77.

Mohammad, B., and Abdelhak, B. 2009. The relationship between money and prices in the Maghreb countries: a cointegration analysis. MPRA paper. No.1274.

Muradoglu, G., Metin, K., and Argac R. 2001. Is there are long run relationship between stock return and monetary variables: Evidence from emerging market. Applied Financial Economic. 11: $641-649$.

Onay, C. 2007. Integration of Bulgaria and Romania to the European Union. The Business Review. 1: 119-126.

Poghossian, T. 2008. Are "New" and "Old" EU Members Becoming More Financially Integrated? A Threshold
Cointegration Analysis. International Economics and Economic Policy. 6(3): $259-281$.

Raiffaisen Research, 2014. Croatia country report.

Rock, M. T., and H. Bonnett, 2004. The Comparative Politics of Corruption: Accounting for the East Asian Paradox in Empirical Studies of Corruption, Growth and Investment. World Development. 32 (6): 999-1017.

Savva, S.C., and Aslanidis, N. 2007. Modelling stock market correlations between new EU member states and the Eurozone. Empirical Economics. 39(2): 337-351.

Schnabl, G. 2004. De Jure Versus De Facto Exchange Rate Stabilization in Central and Eastern Europe. Aussenwirtschaft. 59(2): 171-90.

Sniedovich, M. 2012. Black Swans, New Nostradamuses, Voodoo decision theories, and the science of decision making in the face of severe uncertainty. International Transactions in Operational research. 19(1-2): 253281.

Syllignakis, M., and Kouretas, G. 2006. Long and Short-Run Linkages in CEE Stock Markets: Implications for Portfolio Diversification and Stock Market Integration. William Davidson Institute Working Papers Series. No.832.

Stiftung, BTI 2014 - Croatia Country Report.

Taleb, N. N. 2004. Few and Far Between: Black Swans and the Impossibility of Prediction. Change This. 33(4): 1-16.

Taleb, N. N. 2003. The Black Swan: Why Don't We Learn that we Don't Learn? Highland Forum.

Taleb, N. N. 2007. The Black Swan: The Impact of the Highly Improbable. Get Abstract - The Random House Publishing Group, Inc.

Taleb, N. N. 2009. Crni labud: Utjecaj krajnje nevjerojatnog. Zagreb, Jesenski i Turk.

The Miroslav Krleža Institue of Lexicography. 2013. Croatia - Land and People. 
Vizek, M. and Dadić, T. 2006. Integration of Croatian, CEE and EU Equity Markets: Cointegration Approach. Ekonomski pregled. 57 (9-10): 631-646.

Yau, H.Y., and Nieh, Ch. 2006. Interrelationships among stock prices of Taiwan and Japan and NTD/Yen exchange rate. Journal of Asian Economics. 17: 535-552.

Žiković, S. 2006. Implications of measuring VaR using historical simulation; An example of Zagreb Stock Exchange index - CROBEX in J. Roufagalas (Ed.), Resource allocation and institutions: Explorations in economics, finance and law. 367-389.

\section{APPENDIX}

Appendix A. Correlation of the explanatory variables

(Sample: 2000:1 - 2013:12)

\begin{tabular}{|c|c|c|c|c|c|c|}
\hline & CAP & EXR & INT & CPI & UNE & NPL \\
\hline CAP & $\begin{array}{l}1.0000 \\
00\end{array}$ & $\begin{array}{l}0.5466 \\
84\end{array}$ & $\begin{array}{l}0.3926 \\
89\end{array}$ & $\begin{array}{l}0.4550 \\
45\end{array}$ & $\begin{array}{l}0.2338 \\
12\end{array}$ & $\begin{array}{l}- \\
0.7287 \\
17\end{array}$ \\
\hline EXR & $\begin{array}{l}0.5466 \\
84\end{array}$ & $\begin{array}{l}1.0000 \\
00\end{array}$ & $\begin{array}{l}0.0633 \\
56\end{array}$ & $\begin{array}{l}0.3202 \\
44\end{array}$ & $\begin{array}{l}0.7644 \\
08\end{array}$ & $\begin{array}{l}- \\
0.4119 \\
68\end{array}$ \\
\hline INT & $\begin{array}{l}0.3926 \\
89\end{array}$ & $\begin{array}{l}0.0633 \\
56\end{array}$ & $\begin{array}{l}1.0000 \\
00\end{array}$ & $\begin{array}{l}0.5889 \\
58\end{array}$ & $\begin{array}{l}0.0940 \\
77\end{array}$ & $\begin{array}{l}- \\
0.3122 \\
74\end{array}$ \\
\hline CPI & $\begin{array}{l}0.4550 \\
45\end{array}$ & $\begin{array}{l}0.3202 \\
44\end{array}$ & $\begin{array}{l}0.5889 \\
58\end{array}$ & $\begin{array}{l}1.0000 \\
00\end{array}$ & $\begin{array}{l}0.2260 \\
00\end{array}$ & $\begin{array}{l}- \\
0.1845 \\
20\end{array}$ \\
\hline UNE & $\begin{array}{l}0.2338 \\
12\end{array}$ & $\begin{array}{l}0.7644 \\
08\end{array}$ & $\begin{array}{l}0.0940 \\
77\end{array}$ & $\begin{array}{l}0.2260 \\
00\end{array}$ & $\begin{array}{l}1.0000 \\
00\end{array}$ & $\begin{array}{l}- \\
0.0018 \\
87\end{array}$ \\
\hline NPL & $\begin{array}{l}- \\
0.7287 \\
17\end{array}$ & $\begin{array}{l}- \\
0.4119 \\
68\end{array}$ & $\begin{array}{l}- \\
0.3122 \\
74\end{array}$ & $\begin{array}{l}- \\
0.1845 \\
20\end{array}$ & $\begin{array}{l}- \\
0.0018 \\
87\end{array}$ & $\begin{array}{l}1.0000 \\
00\end{array}$ \\
\hline \multicolumn{7}{|c|}{$\begin{array}{l}\text { Symbols: CAP: capital inflow expressed in percentage of GDP; EXR: } \\
\text { exchange rate expressed as the price of one unit of foreign currency in } \\
\text { units of domestic currency; INT - interest rate p.a.; CPI: consumer price } \\
\text { index (in bnp of domestic currency deflated by GDP deflator); UNE: } \\
\text { unemployment expressed in percentage of the total labour force, NPL: } \\
\text { non-performing loan (loan share of all nominal loans that are at least } 90 \\
\text { days overdue) }\end{array}$} \\
\hline
\end{tabular}

Appendix B. Serial Correlation

(Sample: 2000:1 - 2013:12)

\begin{tabular}{|llll|}
\hline \multicolumn{4}{|l|}{ Breusch-Godfrey Serial Correlation LM Test: } \\
\hline \hline F-statistic & 0.084605 & Prob. F(2,132) & 0.9189 \\
Obs*R-squared & 0.000000 & Prob. Chi-Square(2) & 1.0000 \\
\hline
\end{tabular}

